УДК 341.1

\title{
В.В. Ровнейко
}

\section{ПРОБЛЕМЫ УГОЛОВНО-ПРАВОВОЙ ОЦЕНКИ РЕАБИЛИТАЦИИ НАЦИЗМА КАК ПРЕСТУПЛЕНИЯ МЕЖДУНАРОДНОГО ХАРАКТЕРА}

\begin{abstract}
В статье рассматриваются проблемы международно-правового и уголовно-правового характера, связанные с установлением уголовной ответственности за попытки «реабилитации нацизма» и определением признаков состава преступления, предусмотренного ст. $354^{1}$ УК РФ. В статье проведен анализ соответствия признаков состава указанного преступления характеру и степени его общественной опасности, а также делается вывод о необходимости заключения международного договора о сотрудничестве по вопросам противодействию нацизму, принятия национального закона, определяющего основные понятия и направления для такого противодействия, а также изменения содержания ст. $354^{1}$ УК РФ для того, чтобы привести в соответствие характер и степень общественной опасности, которыми должно обладать преступление против мира и безопасности человечества, и чтобы сфера применения данной статьи при попытках реабилитации нацизма не была ограничена только содержанием приговора Нюрнбергского трибунала, который при всей его неоспоримой значимости не является единственным международным и судебным актом, осуждающим преступления нацистов и их пособников.
\end{abstract}

Ключевые слова: реабилитация нацизма, уголовная ответственность, преступления против мира и безопасности человечества, Вторая мировая война, Нюрнбергский трибунал, Токийский трибунал, Хабаровский процесс, дни воинской славы и памятные даты России, символы воинской славы России.

DOI: $10.35634 / 2412-9593-2021-31-5-882-890$

12 мая 2015 г. «в Астраханской области возбудили уголовное дело против 16-летнего подростка, который “повесил” на своей странице в соцсети архивную фотографию и сочинил к ней подпись. Следователи отдела по расследованию особо важных дел расценили его поступок как оправдание преступлений, установленных приговором Международного трибунала в Нюрнберге (ч. 1 ст. $354^{1}$ УК) - это первый известный случай применения этой части новой статьи Уголовного кодекса, наказывающей за "реабилитацию нацизма"»" .

Статья $354^{1}$ «Реабилитация нацизма» введена в гл. 34 разд. ХІІ «Преступления против мира и безопасности человечества» Уголовного кодекса РФ Федеральным законом от 5 мая 2014 г. ${ }^{2}$ С учетом характера общественной опасности составов преступлений, признаки которых содержатся в статьях данной главы и одноименного раздела УК РФ, эти преступления могут быть отнесены или к международным преступлениям (преступлениям по общему международному праву), или к преступлениям международного характера (конвенционным преступлениям) ${ }^{3}$. Реабилитация нацизма не является исключением, так как международный характер общественной опасности данного преступления не вызывает сомнений. Но, в отличие от других преступлений международного характера, международного договора о сотрудничестве между государствами по борьбе с таким преступлением, как реабилитация нацизма, не существует, хотя национальное законодательство многих государств предусматривает уголовную ответственность, в той или иной форме, за реабилитацию нацизма.

Отсутствие такого договора делает невозможным применение универсальной юрисдикции в отношении данного преступления. Например, в соответствии с УК РФ применение принципа универсальности возможно только «в случаях, предусмотренных международным договором Российской Федерации или иным документом международного характера, содержащим обязательства, призна-

\footnotetext{
${ }^{1}$ Голубев С. 354.1. Ищут себе оправдания. URL: https://zona.media/article/2015/15/05/codex-354-1 (дата обращения: 05.02.2020).

${ }^{2}$ Федеральный закон от 05.05.2014 № 128-Ф3 «О внесении изменений в отдельные законодательные акты Российской Федерации» // Собрание законодательства РФ. 2014. № 19. Ст. 2333.

${ }^{3}$ См., напр.: Лукашук И.И., Наумов А.В. Международное уголовное право: учебник. М.: Спарк, 1999. С. $112-$ 200; Номоконов В.А. Международное уголовное право: учеб. пособие. Владивосток: Изд-во Дальневосточ. унта, 2001. С. 31-41; Международное уголовное право: учеб. пособие / под ред. В.Н. Кудрявцева. 2-е изд. перераб. и доп. М.: Наука, 1999. С. 50-56, 126-180; Иногамова-Хегай Л.В. Международное уголовное право: учеб. пособие для магистрантов. М.: Проспект, 2018. С. 34-38.
} 
ваемые Российской Федерацией в сфере отношений, регулируемых настоящим Кодексом» ${ }^{4}$. То есть для применения универсального принципа необходимым условием является наличие международного договора, содержащего обязательства, признаваемые Российской Федерацией в сфере противодействия реабилитации нацизма.

Наличие общественной опасности реабилитации нацизма признается не только в России и большинстве бывших союзных республик, но и в странах $\mathrm{EC}^{5}$. Данное обстоятельство при условии отсутствия международного договора не позволяет рассматривать его ни в качестве международного, ни в качестве конвенционного преступления. С точки зрения возможности применения универсальной юрисдикции реабилитация нацизма не отличается от «общеуголовных» преступлений, таких, например, как кража или клевета. Этому способствуют и неудачные формулировки, использованные законодателем при определении признаков состава данного преступления, которые (дополнительно к отсутствию международного договора) не позволяют отнести данное преступление к числу преступлений международного характера и критикуются многими авторами ${ }^{6}$.

Следует отметить, во-первых, что не все формы реабилитации нацизма, предусмотренные ст. $354^{1}$ УК РФ, соответствуют по характеру и степени общественной опасности международному преступлению или преступлению международного характера. Некоторые их них затрагивают только внутренние интересы Российской Федерации, являясь по характеру общественной опасности преступлениями против общественной безопасности и общественного порядка (разд. IX УК РФ). Так, ч.3 ст. $354^{1}$ УК РФ «Реабилитация нацизма» предусмотрена ответственность за «распространение выражающих явное неуважение к обществу сведений о днях воинской славы и памятных датах России, связанных с защитой Отечества, а равно осквернение символов воинской славы России, совершенные публично». Имеющие место судебные решения (обвинительные приговоры) вынесены именно по ч. 3 ст. $354^{1}$ УК Р $\Phi^{7}$. Поскольку в ч. 3 ст. $354^{1}$ УК РФ предусмотрена ответственность за распространение сведений исключительно о днях, датах и символах России, то можно сделать вывод, что данные действия не могут рассматриваться ни как преступление международного характера, ни как международное преступление.

Кроме того, в Федеральном законе раскрывается содержание понятий «дни воинской славы России» и «памятные даты России» таким образом, что и к реабилитации нацизма, в полном смысле этого понятия, ч. 3 ст. $354^{1}$ УК РФ имеет отношение не всегда. Так, в ст. 1 Федерального закона «О днях воинской славы и памятных датах России» в качестве дней воинской славы вместе, например, с «27 января - день полного освобождения Ленинграда от фашистской блокады (1944 г.)», установлены: «18 апреля - День победы русских воинов князя Александра Невского над немецкими рыцарями на Чудском озере («Ледовое побоище» 1242 г.)» и «21 сентября - день победы русских полков во главе с великим князем Дмитрием Донским над монголо-татарскими войсками в Куликовской битве $\left(1380\right.$ г.)» ${ }^{8}$, которые не имеют никакого отношения ни ко Второй мировой войне, ни к нацизму.

Аналогично в Федеральном законе решен вопрос и о памятных датах. Так, к памятным датам, относится не только «22 июня - День памяти и скорби - День начала Великой Отечественной войны

\footnotetext{
${ }^{4}$ Уголовный кодекс РФ. Часть 3 ст. 12. URL: http://www.pravo.gov.ru

${ }^{5}$ Только в 2007-2008 годах за отрицание Холокоста в странах Европейского союза были осуждены не менее 10 человек / А.С. Брод. О реабилитации неонацизма, эскалации ксенофобии в Европе и США. Общественная палата Российской Федерации (26 января 2009) / Цит. по: Уголовное преследование за отрицание Холокоста. URL: https://ru.wikipedia.org/wiki/Уголовное_преследование_отрицания_Холокоста\#Хронология_уголовных_ дел_в_странах_ЕС (дата обращения: 05.02.2020).

${ }^{6}$ Кибальник А.Г., Иванов А.Ю. Реабилитация нацизма как преступление против мира и безопасности человечества: монография. М.: Юрлитинформ, 2019; Спиридонова О.Е. Неопределенность уголовно-правового регулирования и ее последствия (на примере ст. 354.1 УК РФ) // Уголовное право: стратегия развития в XXI веке. М., 2017. С. 537-540; Левандовская М.Г. Реабилитация нацизма как преступление // Вестник ун-та имени О.Е. Кутафина (МГЮА). Вып.: Уголовное право. 2018. №12 (52). С. 155-162; Макаров А.В., Романенко А.С. Уголовная ответственность за реабилитацию нацизма // Российский следователь. 2016. № 5.

${ }^{7}$ Форма № 10-а «Отчет о числе осужденных по всем составам преступлений Уголовного кодекса Российской Федерации» / Сводные статистические сведения о состоянии судимости в России за 2018 год / Данные судебной статистики Судебного департамента при Верховном Суде РФ. URL: http://www.cdep.ru/index.php? id $=79 \&$ item $=4894$.

${ }^{8}$ Федеральный закон от 13.03.1995 № 32-Ф3 (ред. от 03.08.2018) «О днях воинской славы и памятных датах России». Ст. 1. URL: http://www.pravo.gov.ru (дата обращения: 03.08.2018).
} 
(1941 г.)», но и «25 января - День российского студенчества», а также «12 апреля - День космонавтики» ${ }^{9}$ и другие важные для России даты, но не имеющие отношения к нацизму.

Осквернение символов воинской славы России тоже не всегда связано со Второй мировой войной и нацизмом. Сложность заключается еще и в том, что понятие «символ воинской славы России» не имеет нормативного определения и, по сути, является оценочным понятием. Как отмечают А.Г. Кибальник и А.Ю. Иванов, «практически каждый предмет, имеющий то или иное отношение к воинской славе России, может быть признан ее символом» ${ }^{10}$. Они же отмечают, что «использование в ст. $354^{1}$ УК РФ термина "символ воинской славы России" само по себе является проявлением уголовноправового запрета. Последний может привести к неоправданности уголовно-правовой репрессии за деяния, смысл которых совершенно противоположен либо не совпадает с юридической сущностью деяний, образующих объективную сторону основного состава реабилитации нацизма. Автор этой точки зрения довольно удачно приводит пример с георгиевской лентой, происхождение и первоначальное использование которой не связано ни со Второй мировой войной, ни с борьбой с нацизмом» ${ }^{11}$.

Следует полностью согласиться с их выводом, что «ни одно из деяний, указанных в ч. 3 ст. $354^{1}$ УК РФ, не может рассматриваться в качестве акта реабилитации нацизма и в принципе в качестве преступления против мира и безопасности человечества. Иными словами, законодатель допустил ошибку, криминализировав данные деяния (общественная опасность которых сама по себе не ставится под сомнение) в главе 34 УК РФ» ${ }^{12}$.

Представляется, что формулировки признаков состава преступления, предусмотренные в чч. 1 и 2 ст. $354^{1}$ УК РФ, тоже не являются безупречными как с точки зрения возможности их отнесения к преступлениям по международному праву, так и с точки зрения примененной законодательной техники.

Формы реабилитации нацизма предусмотрены ч. 1 ст. $354^{1}$ УК РФ. Исходя из диспозиции уголовно-правовой нормы можно выделить три самостоятельные формы реабилитации нацизма:

1) отрицание фактов, установленных приговором Международного военного трибунала для суда и наказания главных военных преступников европейских стран оси;

2) одобрение преступлений, установленных указанным приговором;

3) распространение заведомо ложных сведений о деятельности СССР в годы Второй мировой войны.

В первую очередь следует отменить расхождение между названием статьи «Реабилитация нацизма» и ее содержанием. Сложно признать корректным использование понятия «реабилитация» применительно к нацизму в контексте указанной статьи и с учетом тех форм, в которых, по мнению законодателя, она может выражаться. Как справедливо отмечает М.Г. Левандовская, понятие «реабилитация» означает не столько оправдание, сколько «восстановление в правах» 13 . Тем формам реабилитации нацизма, которые предусмотрены ч. 1 ст. $354^{1}$ УК РФ («отрицание фактов, установленных приговором», «одобрению преступлений», «распространение заведомо ложных сведений о деятельности СССР»), больше соответствовали бы такие понятия, как «оправдание нацизма» и «пропаганда нацизма».

В Уголовном кодексе РФ определено содержание понятий «оправдание» и «пропаганда» при определении признаков состава преступления, предусмотренного ст. $205^{2}$ УК РФ: «Публичные призывы к осуществлению террористической деятельности, публичное оправдание терроризма или пропаганда терроризма». Представляется, что и в данном случае следовало бы использовать те приемы юридической техники и те законодательные формулировки, которые уже применены в ст. $205^{2}$ УК

\footnotetext{
${ }^{9}$ Федеральный закон от 13.03.1995 № 32-Ф3 (ред. от 03.08.2018) «О днях воинской славы и памятных датах России». Ст. 1.1. URL: http://www.pravo.gov.ru (дата обращения: 03.08.2018).

${ }^{10}$ Кибальник А.Г., Иванов А.Ю. Реабилитация нацизма как преступление против мира и безопасности человечества: монография. М.: Юрлитинформ, 2019. С. 107.

${ }^{11}$ Спиридонова O.Е. Неопределенность уголовно-правового регулирования и ее последствия (на примере ст. 354.1 УК РФ) // Уголовное право: стратегия развития в XXI веке. М., 2017. С. 537-540 / Цит. по: Кибальник А.Г., Иванов А.Ю. Реабилитация нацизма как преступление против мира и безопасности человечества: монография. М.: Юрлитинформ, 2019. С. 107.

${ }^{12}$ Кибальник А.Г., Иванов А.Ю. Реабилитация нацизма как преступление против мира и безопасности человечества: монография. М.: Юрлитинформ, 2019. С. 108.

${ }^{13}$ См., напр.: Левандовская М.Г. Реабилитация нацизма как преступление // Вестник ун-та имени О.Е. Кутафина (МГЮА). Вып.: Уголовное право. 2018. № 12 (52). С. 157.
} 
Р $\Phi^{14}$. В Примечании к указанной статье, например, предусмотрено, что «под публичным оправданием терроризма понимается публичное заявление о признании идеологии и практики терроризма правильными, нуждающимися в поддержке и подражании» ${ }^{15}$, а «под пропагандой терроризма понимается деятельность по распространению материалов и (или) информации, направленных на формирование у лица идеологии терроризма, убежденности в ее привлекательности либо представления о допустимости осуществления террористической деятельности» ${ }^{16}$. Аналогичные формулировки, примененные к оправданию и пропаганде нацизма, будут вполне логичными и допустимыми: «Под публичным оправданием нацизма понимается публичное заявление о признании идеологии и практики нацизма правильными, нуждающимися в поддержке и подражании»; «Под пропагандой нацизма понимается деятельность по распространению материалов и (или) информации, направленных на формирование у лица идеологии нацизма, убежденности в ее привлекательности либо представления о допустимости осуществления националистической деятельности». Таким образом, если использовать уже существующие в Уголовном кодексе РФ формулировки в названии, содержании и примечании к ст. $354^{1}$ УК РФ, то такая законодательная конструкция была бы более удачной, хотя она тоже не лишена некоторых недостатков.

Спорность формулировки такой формы реабилитации нацизма, как «распространение заведомо ложных сведений о деятельности СССР в годы Второй мировой войны», связана еще и с тем, что клевета в отношении СССР не предполагает автоматического оправдания (реабилитации) нацизма.

Кроме того, определить, какие сведения о деятельности СССР в годы Второй мировой войны являются истинными, а какие - ложными, достаточно трудно ${ }^{17}$, так как «до сих пор не известны подробности многих военных операций..., а соответствующие документы засекречены и поныне» ${ }^{18}$. Следует согласиться с тем, что в настоящее время «речь должна идти о деятельности СССР, официально зафиксированной в приговоре Нюрнбергского трибунала. В этом документе, например, однозначно определен факт развязывания нацистской Германией агрессивной войны против Советского Союза» ${ }^{19}$, поскольку именно данный факт оспаривается, например, польскими лидерами, и на основании этого предъявляется требование о репарации за ущерб во время войны от России ${ }^{20}$. Как указал Сергей Лавров, «попытки оболгать Россию с точки зрения причин и итогов Второй мировой войны, а также использовать эту ложь для того, чтобы ослабить позиции страны на международной арене, будут продолжаться» ${ }^{21}$.

Другие формы реабилитации нацизма - «отрицание фактов, установленных приговором Международного военного трибунала для суда и наказания главных военных преступников европейских стран оси» и «одобрение преступлений, установленных указанным приговором» - не учитывают того, что такая формулировка ограничивает сферу применения статьи, так как приговор Нюрнбергского трибунала, который, при всей его неоспоримой значимости, не является единственным международ-

\footnotetext{
${ }^{14}$ Введена Федеральным законом от 27.07.2006 № 153-Ф3 «О внесении изменений в отдельные законодательные акты Российской Федерации в связи с принятием Федерального закона "О ратификации конвенции совета Европы о предупреждении терроризма" и Федерального закона "О противодействии терроризму"» от 27.07.2006 № 153-Ф3 (в ред. от 06.07.2016 № 375-Ф3). URL: http://pravo.gov.ru

${ }^{15}$ Примечание 1 к ст. 205.2 УК РФ.

${ }^{16}$ Примечание 1.1 к ст. 205.2 УК РФ.

17 До сих пор не все документы рассекречены и доступны. Большое количество документов к 75-летию Победы было размещено на интернет-портале «Память народа». Министерство обороны РФ и Корпорация ЭЛАР представляют крупнейший в мире интернет-портал подлинных документов о Второй мировой войне (1939-1945) и Великой Отечественной войне (1941-1945). В рамках проекта «Память народа» впервые оцифровано и выложено в Интернет 425 тысяч архивных документов фронтов, армий и других соединений Красной Армии / Интернет-портал подлинных документов о Второй мировой войне (1939-1945) и Великой Отечественной войне (19411945) «Память народа». URL: https://pamyat-naroda.ru/ops/

${ }^{18}$ Кибальник А.Г., Иванов А.Ю. Уголовная ответственность за реабилитацию нацизма // Уголовное право. 2015. № 4 // СПС «КонсультантПлюс».

${ }^{19}$ Кибальник А.Г., Иванов А.Ю. Уголовная ответственность за реабилитацию нацизма // Уголовное право. 2015. № 4 // СПС «КонсультантПлюс».

${ }^{20}$ Качиньский потребовал от России репарации за ущерб во время войны. URL: https://ria.ru/20200125/ 1563861368.html (дата обращения: 25.01.2020).

${ }^{21}$ Историк удивился из-за слов премьера Польши о Второй мировой войне. URL: https://ria.ru/20200123/ 1563761612.html?in=t (дата обращения: 25.01.2020).
} 
ным и судебным актом, осуждающим преступления нацистов и их пособников, совершенные во время Второй мировой войны. Кроме Нюрнбергского трибунала, существовал Международный военный трибунал для Дальнего Востока (Токийский трибунал), который был создан «по образу и подобию» Нюрнбергского трибунала, но обладал иной территориальной подсудностью. Дела о преступлениях, которые рассматривались Токийским трибуналом, были столь же значимыми, а сами преступления такими же тяжкими, как и те, которые рассматривались Нюрнбергским трибуналом (преступления против мира, массовые убийства, преступления против человечности, например, Нанкинская резня, Батаанский марш смерти). Отрицание фактов, установленных приговором Токийского трибунала, если и не может в полном смысле рассматриваться в качестве оправдания (реабилитации) нацизма, то используется для тех же целей: «оболгать Россию с точки зрения причин и итогов Второй мировой войны». Общественная опасность таких действий так же высока, как и отрицание фактов, установленных Нюрнбергским трибуналом.

Следует отметить, что дела о преступлениях большинства нацистских преступников (не являвшихся руководителями Рейха) и военных преступников (не из числа высшего военного и гражданского руководства Японской империи) и их пособников рассматривались национальными судами государств. Большое количество таких уголовных дел рассматривалось и судами РСФСР ${ }^{22}$. Самым известным из них является Хабаровский процесс 1949 г. над бывшими военнослужащими Квантунской армии, обвиняемыми в создании бактериологического оружия и проведении экспериментов над военнопленными $^{23}$. Уголовные дела о геноциде в годы Второй мировой войны возбуждаются и расследуются и в наши дни ${ }^{24}$. Отрицание фактов совершения преступлений против мира, человечности, военных преступлений и геноцида, установленных национальными судами государств, обладая высокой степенью общественной опасности, не подпадает под действие статьи об оправдании (реабилитации) нацизма.

Указание в ч. 1 ст. $354^{1}$ УК РФ на отрицание фактов, установленных приговором только Нюрнбергского трибунала, не позволяет рассматривать в качестве преступления отрицание фактов совершения военных преступлений и других преступлений против мира и безопасности человечества во время Второй мировой войны и одобрение таких преступлений, дела о которых рассматривались не Нюрнбергским трибуналом, а Токийским трибуналом или национальными судами государств.

Таким образом, отрицание фактов, установленных не только «приговором Международного военного трибунала для суда и наказания главных военных преступников европейских стран оси», но и приговорами других судов по делам о преступлениях против мира и безопасности человечества, совершенных во время Второй мировой войны, «одобрение преступлений, установленных» не только указанным приговором, но и приговорами других судов, должно охватываться признаками состава преступления, ответственность за которое предусмотрена ст. $354^{1}$ УК РФ.

В качестве квалифицирующих признаков оправдания (реабилитации) нацизма в ч. 2 ст. 354.1 УК РФ предусмотрены такие квалифицирующие признаки, как «с использованием СМИ» и «с искусственным созданием доказательств обвинения». Их формулировки сложно признать корректными.

\footnotetext{
${ }^{22}$ Федеральное архивное агентство совместно с ФСБ, МВД, МИД и Минобороны России с привлечением документов 44 региональных архивов представляют интернет-проект «Преступления нацистов и их пособников против мирного населения СССР в годы Великой Отечественной войны 1941-1945 гг.» (доступен на сайте ведомства в день 75-летия окончания Второй мировой войны). Публикация включает в себя более 2600 документов, в том числе 10 часов фонозаписей и 3 часа кинохроники. Значительная часть специально рассекречена для проекта. URL: https://victims.rusarchives.ru/02-09-2020-federalnyy-arkhivnyy-proekt-press-reliz

${ }^{23}$ Ковалев Б.Н., Асташкин Д. Проект: Советский Нюрнберг (Источник информации - портал История.РФ). URL: https:/histrf.ru/biblioteka/Soviet-Nuremberg; Хабаровский процесс / Проект «Советский Нюрнберг» / Источник информации - портал История РФ. URL: https://histrf.ru/biblioteka/Soviet-Nuremberg/Khabarovsky-process

${ }^{24}$ Всего в 2019-2020 годах Следственный комитет возбудил четыре уголовных дела о геноциде в годы Второй мировой войны. 9 апреля было возбуждено дело о расстрелах нацистами мирного населения Ростовской области в августе 1942 года (11 и 12 августа военнослужащие СС убили в этих местах более 30 тысяч человек, в основном евреев и партийных работников, в Змиевской балке и других населенных пунктах); в феврале - дело об убийстве детей в оккупированном Ейске (9 октября 1942 г. нацисты убили и похоронили в братской могиле 214 воспитанников местного детского дома); в мае 2019 г.- дело о массовых расстрелах жителей деревни Жестяная Горка (Новгородская область) в период с 1941 по 1943 год. Как и в случае с делом о финских лагерях в Петрозаводске, остальные дела также возбуждались в связи с хорошо изученными событиями / Екатерина Мищук. Зачем Следственный комитет заводит новые уголовные дела о зверствах нацистов в годы войны. 8 июня 2020 года. URL: https://www.currenttime.tv/a/nazi-crimes-peobed-again/30655103.html
} 
Такой признак, как оправдание (реабилитация) нацизма «с использованием средств массовой информации» не позволяет рассматривать в качестве квалифицированного и, значит, представляющего повышенную степень общественной опасности преступления случай, когда для оправдания нацизма используется, например, сеть «Интернет». Между тем в большинстве случаев имеет место распространение информации через сеть «Интернет». Например, в Кемеровской области вынесен приговор за реабилитацию нацизма (действия квалифицированы по ч. 1 ст. 354.1 УК РФ) 20-летнему жителю, «который размещал на своей странице в социальной сети тексты, в которых отрицал факты, установленные приговором Международного военного трибунала» ${ }^{25}$.

В большинстве составов преступлений, предусматривающих в качестве признака основного или квалифицированного состава «с использованием средств массовой информации», как правило, предусмотрен и признак «с использованием средств массовой информации либо электронных или информационно-телекоммуникационных сетей (включая сеть "Интернет")» ${ }^{26}$. Такая же законодательная конструкция необходима и в ч. 2 ст. $354^{1}$ УК РФ.

Сложно согласиться и с формулировкой такого квалифицирующего признака оправдания (реабилитации) нацизма, как совершенное «с искусственным созданием доказательств обвинения». Доказательство, в юридическом смысле, не может существовать вне юридического процесса по какомулибо делу ${ }^{27}$. Понятие «обвинения» имеет два смысла (процессуально-правовой и материальноправовой): во-первых, обвинение - это процессуальная функция, то есть деятельность государственных органов (в международных судах - специально уполномоченных органов и должностных лиц) по изобличению лица в совершении преступления, во-вторых, обвинение - это совокупность инкриминируемых лицу фактов, образующих состав преступления. В любом случае обвинение в юридическом смысле не может существовать само по себе, вне судопроизводства по конкретному делу. Фальсификация доказательств по характеру общественной опасности является преступлением против правосудия. В настоящее время деятельность Нюрнбергского и Токийского трибуналов завершена, большинство приговоров национальных судов государств состоялось. Какое дело может иметь место в данном случае, какой суд может рассматривать такое дело и в отношении кого выдвинуто обвинение - это вопросы, ответ на которые не известен. Если имеет место распространение ложных сведений о деятельности СССР в годы Второй мировой войны и фальсификация фактов в связи с этим, а также обман в виде искажения информации или умалчивания об имевших место фактах, то такие признаки должны быть отражены в понятных правоприменителю юридических формулировках.

Содержание ст. $354^{1}$ УК РФ направлено на противодействие нацизму (национал-социализму) и такой его форме проявления, как фашизм, который являлся официальной политической идеологией в Германии в 1933-1945 гг. Необходимо отметить и то обстоятельство, что кроме германского фашизма как формы нацизма (национал-социализма), существовал и итальянский фашизм, который во многом предопределил возникновение германского. Однако формулировка признаков состава реабилитации нацизма не охватывает эти формы и виды проявления нацизма. Такая ситуация во многом обусловлена отсутствием нормативного определения понятия «нацизм». М.Г. Левандовская отмечает, что «законодателем неоднократно предпринимались весьма удачные попытки официального толкования понятия "нацизм"»" ${ }^{28}$, ссылаясь на проект Федерального закона «О недопустимости действий по реабилитации нацизма, героизации нацистских преступников и их пособников, отрицанию Холокоста» ${ }^{29}$.

\footnotetext{
${ }^{25}$ Бухтояров П.В. В Кемеровской области вынесен приговор за реабилитацию нацизма // Прокурор. 2016. № 4 / СПС «КонсультантПлюс».

${ }^{26}$ См., напр.: Пункт «б» ч. 2 ст. 228.1 УК РФ.

${ }^{27}$ См., напр.: Ст. 74 УПК РФ: «Доказательствами по уголовному делу являются любые сведения, на основе которых суд, прокурор, следователь, дознаватель в порядке, определенном настоящим Кодексом, устанавливает наличие или отсутствие обстоятельств, подлежащих доказыванию при производстве по уголовному делу, а также иных обстоятельств, имеющих значение для уголовного дела»; ст. 55 ГПК РФ: «Доказательствами по делу являются полученные в предусмотренном законом порядке сведения о фактах, на основе которых суд устанавливает наличие или отсутствие обстоятельств, обосновывающих требования и возражения сторон, а также иных обстоятельств, имеющих значение для правильного рассмотрения и разрешения дела».

28 Левандовская М.Г. Реабилитация нацизма как преступление // Вестник ун-та имени О.Е. Кутафина (МГЮА). Вып.: Уголовное право. 2018. №12 (52). С. 161.

${ }^{29}$ См., напр.: Проект Федерального закона № 246071-6 «О недопустимости действий по реабилитации нацизма, героизации нацистских преступников и их пособников, отрицанию Холокоста» (ред., внесенная в ГД ФС РФ,
} 
Таких проектов было несколько: был еще один законопроект ${ }^{30}$, который был отклонен без указания причин ${ }^{31}$.

Возможно, что основные понятия, которые содержат определения признаков такого преступления, как оправдание и пропаганда (реабилитация) нацизма, могут быть предусмотрены в международном договоре о сотрудничестве между государствами по борьбе с публичным оправданием нацизма и пропагандой нацизма, отрицанием фактов совершения и одобрением совершения военных преступлений, преступлений против мира и безопасности человечества.

Условием для заключения такого договора может являться то обстоятельство, что во многих государствах деяния, которые предусмотрены ст. $354^{1}$ УК РФ, являются преступлениями. Но «анализ уголовного законодательства зарубежных государств позволяет утверждать, что в нем отсутствуют нормы, полностью идентичные запрету на реабилитацию нацизма в российском уголовном законе» ${ }^{32}$. Авторы выделяют «три вида законодательной реакции на реабилитацию нацизма в зарубежных государствах:

- государства, в которых деяния, образующие реабилитацию нацизма, запрещены непосредственно в уголовном законодательстве;

- государства, в которых изданы специальные законы, запрещающие проявления реабилитации нацизма (в первую очередь отрицание Холокоста);

- государства, в которых отсутствует специальный уголовно-правовой запрет на реабилитацию нацизма, в отношении которого действуют нормы о преступлениях против мира и безопасности либо экстремистских преступлениях» ${ }^{33}$.

В том или ином виде такие нормы существуют в Германии, Израиле, Австрии, Франции, Бельгии, Венгрии, Греции, Италии, Польше, Румынии, Чехии, Великобритании, Ирландии, Испании, Нидерландах, Португалии, странах Скандинавии, Финляндии, Швейцарии, многих государствах, бывших частью СССР и СФРЮ ${ }^{34}$. Заключение такого международного договора возможно, так как наличие соответствующих уголовно-правовых запретов в национальном праве государства позволяет обеспечить выполнение требования о «двойной криминальности» рассматриваемых деяний. Обязательство распространить свою национальную уголовную юрисдикцию на деяния, признаваемые преступлениями согласно такому договору, будет выполнимым ${ }^{35}$.

Проблема заключается в том, что «некоторые из этих стран приравняли коммунизм к нацизму и ввели уголовную ответственность не только за оправдание и пропаганду нацизма, но и за «отрицание "преступлений коммунизма" или "коммунистического геноцида" 36 , что, по нашему мнению, ... свидетельствует об использовании средств уголовно-правовой охраны для утверждения некоторыми законодателями собственного видения истории и приравнивания под страхом наказания новых идеологических догм вместо старых» ${ }^{37}$. Возможность заключения международного договора о сотрудничестве по противодействию нацизму с такими государствами маловероятна.

текст по состоянию на 25.03.2013) / Цит. по: М.Г. Левандовская Реабилитация нацизма как преступление // Вестник ун-та имени О.Е. Кутафина (МГЮА). Вып.: Уголовное право. 2018. № 12 (52). С. 161.

${ }^{30}$ Проект Федерального закона № 504872-6 «О противодействии реабилитации нацизма, героизации нацистских преступников и их пособников» (ред., внесенная в ГД ФС РФ, текст по состоянию на 22.04.2014). URL: http://asozd.duma.gov.ru по состоянию на 22.04.2014.

${ }^{31}$ Постановление ГД ФС РФ от 22.05.2018 № 4021-7 ГД «О проекте Федерального закона № $504872-6$ "О противодействии реабилитации нацизма, героизации нацистских преступников и их пособников"»// Собрание законодательства РФ. 2018. № 22. Ст. 3099.

${ }^{32}$ Кибальник А.Г., Иванов А.Ю. Реабилитация нацизма как преступление против мира и безопасности человечества: монография. М.: Юрлитинформ, 2019. С. 38.

${ }^{33}$ Там же.

34 Там же. С. 36-47.

${ }^{35}$ См., напр.: Статью 5 Конвенции ООН против транснациональной организованной преступности (Принята резолюцией 55/25 ГА от 15 ноября 2000 года): «Каждое Государство-участник принимает такие законодательные и другие меры, какие могут потребоваться, с тем чтобы признать в качестве уголовно наказуемых следующие деяния, когда они совершаются умышленно». URL: https://www.un.org/ru/documents/decl_conv/conventions/ orgcrime.shtml

${ }^{36}$ См.: Додонов В.Н. Уголовно-правовая охрана исторической правды: зарубежный опыт и развитие российского законодательства // Вестник Академии Генеральной прокуратуры РФ. 2014. №3 (41). С. 88 / Цит. по: Левандовская М.Г. Реабилитация нацизма как преступление // Вестник ун-та имени О.Е. Кутафина (МГЮА). Вып.: Уголовное право. 2018. №12 (52). С. 157.

37 Левандовская М.Г. Реабилитация нацизма как преступление. С. 157. 
Несмотря на рассмотренные выше недостатки криминализации оправдания и пропаганды нацизма в российском уголовном законе трудно согласиться с мнением авторов, которые предлагают полностью исключить ст. $354^{1}$ из УК РФ. Например, Л.В. Иногамова-Хегай отмечает, что «последние годы характеризуются доминированием коллизии (конкуренции) уголовно-правовых норм субъективного свойства. Появление ст. $354^{1}$ "Реабилитация нацизма" УК, предусматривающей уголовную ответственность за публичное отрицание фактов, установленных приговором Нюрнбергского трибунала, одобрение преступлений, установленных этим приговором, распространение заведомо ложных сведений о деятельности СССР в годы Второй мировой войны, публичное распространение выражающих явное неуважение к обществу сведений о днях воинской славы и памятных датах России, связанных с защитой Отечества, осквернение символов воинской славы России является примером избыточной конкуренции уголовно-правовых норм... Статья $354^{1}$ УК РФ является ненужной, лишней в УК, и ее лучше исключить из уголовного закона» ${ }^{38}$.

А.А. Кондрашова делает вывод о том, что в УК РФ при формулировании признаков состава данного преступления имеют место недостатки юридической техники: «Применение негодных юридических средств (понятийного аппарата, оценочных терминов), позволяющих произвольно в правоприменительной практике применять закон, прежде всего в интересах правоохранительных органов и в рамках избирательного правоприменения. Это все уголовное законодательство, устанавливающее ответственность за экстремизм ..., реабилитации нацизма (ст. 354.1 УК РФ), административное законодательство об ответственности за демонстрацию нацистской атрибутики (ст. 20.3 Кодекса Российской Федерации об административных правонарушениях, КоАП РФ)...» ${ }^{39}$.

Можно согласиться с такими утверждениями только отчасти. Уголовную ответственность за публичное распространение выражающих явное неуважение к обществу сведений о днях воинской славы и памятных датах России, связанных с защитой Отечества, осквернение символов воинской славы России следует предусмотреть в другом разделе Уголовного кодекса РФ, исключив из ст. $354^{1}$ УК РФ ч. 3.

Части 1 и 2 ст. $354^{1}$ УК РФ требуют существенных изменений для того, чтобы соответствовать по содержанию тому характеру и степени общественной опасности, которыми должно обладать преступление, ответственность за которое предусмотрена статьей, содержащейся в главе о преступлениях против мира и безопасности человечества, а сфера применения статьи о реабилитации (оправдании) нацизма не была ограничена содержанием фактов, установленных приговором Нюрнбергского трибунала, и распространялась на все случаи оправдания и пропаганды идей нацизма.

Поступила в редакцию 17.07.2021

Ровнейко Вера Владимировна, кандидат юридических наук, доцент, доцент кафедры уголовного права и криминологии ФГБОУ ВО «Удмуртский государственный университет» 426034, Россия, г. Ижевск, ул. Университетская, 1 (корп. 4) E-mail: veravr2012@mail.ru

\title{
V.V. Rovneiko \\ PROBLEMS OF CRIMINAL - LEGAL ASSESSMENT OF REHABILITATION NAZISM AS AN INTERNATIONAL CRIME
}

\author{
DOI: $10.35634 / 2412-9593-2021-31-5-882-890$
}

The article deals with the problems of international law and criminal law related to the establishment of criminal liability for attempts to "rehabilitate Nazism" and the definition of signs of the corpus delicti for in Article $354^{1}$ of the Criminal Code of the Russian Federation. In the article there are analyze correspondence of the signs of the corpus delicti by the nature and degree of crime public danger, and also concludes about necessary to conclude an international cooperation agreement for countering Nazism, adopt a national law defining the basic concepts and directions for such counter-

\footnotetext{
${ }^{38}$ Иногамова-Хегай Л.В. Концептуальные основы конкуренции уголовно-правовых норм: монография. М.: Норма, Инфра-М, 2015 // СПС «КонсультантПлюс».

${ }^{39}$ Кондрашова А.А. О правовых и «неправовых» законах, критерии отграничения и российская правовая реальность // Конституционное и муниципальное право. 2019. №1 1 // СПС «КонсультантПлюс».
} 
action, as well as change the content of Article $354^{1}$ of the Criminal Code of the Russian Federation in order to bring the nature and degree of public danger into line with those that a crime against the peace and security of mankind should possess, and that the scope of application of this article in attempts to rehabilitate Nazism was not limited only to the content of the verdict of the Nuremberg Tribunal, which, for all its indisputable significance, is not the only one international and court act condemning the crimes of the Nazis and their accessories.

Keywords: rehabilitation of Nazism, criminal liability, crimes against the peace and security of mankind, world war II, Nuremberg Tribunal, Tokyo Tribunal, Khabarovsk trial, Days of military glory and memorable dates of Russia, symbols of russian military glory.

Received 17.07.2021

Rovneyko V.V., Candidate of Law, Associate Professor,

Associate Professor at Department of criminal law and criminology

Udmurt State University

Universitetskaya st., 1/4, Izhevsk, Russia, 426034

E-mail: veravr2012@mail.ru 